\title{
A new species of the wasp genus Trypoxylon from southern Brazil, with notes on the systematics of Pisoxylon (Hymenoptera, Crabronidae)
}

\author{
David Barros Muniz ${ }^{1,2}$ \& Gabriel A.R. Melo, ${ }^{1,3}$ \\ ${ }^{1}$ Universidade Federal do Paraná (UFPR), Setor de Ciências Biológicas, Departamento de Zoologia (DZO0), \\ Laboratório de Biologia Comparada de Hymenoptera (LBCH). Curitiba, PR, Brasil. \\ 2 ORCID: http://orcid.org/0000-0003-1152-2376. E-mail: david_bio@yaho0.com.br (correspondent author) \\ 3 ORCID: http://orcid.org/0000-0001-9042-3899. E-mail: garmelo@ufpr.br
}

\begin{abstract}
A new species of Trypoxylon is described from females and males collected in trap-nests and Malaise traps disposed in sites of Atlantic forest in southern Brazil (Paraná and São Paulo states). Trypoxylon basirufum sp. nov. is structurally very similar to Pisoxylon roosevelti Antropov, differing in details of the color pattern, clypeal apex, male antenna and propleura. In an ongoing molecular phylogenetic study of the genus Trypoxylon, T. basirufum sp. nov. did not group with Pisoxylon amenkei Antropov, a species very close morphologically to P. xanthosoma Menke, the type species of Pisoxylon. Based on these results, the scope of the Neotropical wasp genus Pisoxylon Menke is changed to include only the type species and P. amenkei, and consequently Pisoxylon roosevelti is transferred to Trypoxylon s. str.
\end{abstract}

Keywords. Digger-wasps; Crabroninae; Neotropics; Taxonomy; Trypoxylini.

\section{INTRODUCTION}

Trypoxylon is the largest genus within the tribe Trypoxylini, with distribution in all biogeographic regions. Currently, the genus has a total of 635 valid species, 165 of them from the Neotropical region (Amarante, 2002, 2005; Pulawski, 2020). Trypoxylon has been divided by Richards (1934) into the subgenera T. (Trypoxylon) and T. (Trypargilum). Pisoxylon, a genus proposed by Menke (1968) for a single species, P. xanthosoma Menke, 1968, and originally based only on the male sex, has many features in common with Trypoxylon. Antropov (1998) published a revision of Pisoxylon, in which he added two new species to it, $P$. amenkei Antropov, 1998, and P. roosevelti Antropov, 1998 and described the female of the type species, even though the association with the male has been formally done earlier by Morato \& Campos (1994). While the former species closely resembles the type species, the inclusion of $P$. roosevelti represented a considerable broadening in the scope of the genus.

The compact metasoma is the only autapomorphy described by Menke (1968) for Pisoxylon. However, as emphasized by Amarante (1995) in the discussion of his Trypoxylon mojuba, Pisoxylon and Trypoxylon cannot be distinguished using this character only. According to him, Trypoxylon differs from Pisoxylon also in the presence of a propodeal sternite and lateral propodeal carinae. On the other hand, Antropov (1998) argued that Amarante's "propodeal sternite" is not a sclerite but a derivative of the intersegmental membrane, as indicated by the absence of associated muscles, and that this structure was far from being present in all representatives of the nominotypical subgenus of Trypoxylon. Similarly, the lateral propodeal carina is absent in many species of Trypoxylon (Trypoxylon) (e.g., in the fabricator species group). Consequently, the only character distinguishing Pisoxylon from Trypoxylon is the compact abdomen combined with the absence of propodeal lateral carinae.

In an ongoing study of the phylogenetic relationships within Trypoxylon, including the positioning of Pisoxylon, we noticed the great morphological disparity of $P$. roosevelti in comparison with the other two species of Pisoxylon and a strong similarity of this species with some species of Trypoxylon s. str. from the fabricator group. We have also recognized a new species from the Atlantic forest of southern and southeastern Brazil that closely resembles Antropov's Pisoxylon roosevelti. DNA-sequence data from this new taxon revealed that it did not group with Pisoxylon amenkei as expected, but with other species of Trypoxylon s. str. (Muniz and Melo, unpublished data). 
In the present contribution, we change the scope of Pisoxylon, by transferring P. roosevelti to Trypoxylon s. str. and describe a new species of Trypoxylon resembling Antropov's species.

\section{MATERIAL AND METHODS}

In addition to the material from the 'Coleção Entomológica Padre Jesus Santiago Moure', Universidade Federal do Paraná (DZUP), specimens were loaned from the following institutions and curators: MZUSP, Museu de Zoologia da Universidade de São Paulo, São Paulo, Brazil - Dr. Carlos Roberto Brandão; RPSP, Universidade de São Paulo, Ribeirão Preto, São Paulo, Brazil - Dr. Carlos Alberto Garófalo; AMNH, American Museum Natural of History, New York, USA - Dr. James M. Carpenter.

The terminology for the external morphology follows Bohart \& Menke (1976) supplemented by Richards (1934). The flagellomeres are referred as F1 to F10 in females and F1 to F11 in males. In the item 'Examined material', all label data are transcribed, with information from each label presented between quotation marks, and the different lines in the label by a backslash ( $($ ). Specimens were photographed using a Leica DFC 500 camera attached to a Leica MZ16 stereomicroscope. The images were treated using the software Auto-Montage Zerene Stacker (Zerene Systems LLC) and edited in Gimp 2.8.22 (GNU General Public License).

\section{Taxonomy}

\section{Scope of Pisoxylon and its status in relation to Trypoxylon}

Considering the three species of Pisoxylon recognized by Antropov (1998) in his revision, P. amenkei and P. xanthosoma are very close to each other morphologically, having many features in common. They differ from one another only by the length of the undivided part of the medial carina, the distance between the lateral ocellus and the corresponding inner eye margin, the thickness of the striations on the dorsal part of the propodeum and coloring of clypeal disc, the mesosoma, the metasoma and the silvery pubescence present in $P$. amenkei against the golden pubescence in $P$.xanthosoma.

On the other hand, $P$. roosevelti differs from these two species in many aspects: metapleura dorsally with a dilated lamellar margin; a small incision in the inner margin of the mandible; medial lobe of clypeus nearly straight in frontal view, with short rectangular protrusion in females; supraclypeal area somewhat longer than wide; lower part of frons with short, entire medial carina; dorsal part of propodeum with fine punctation and short transverse striae along medial groove; lateral part of propodeum without punctation and pilosity; males with antennae modified, at least with the F4 and F8 somewhat thickened and excised beneath; entire mesosoma black.

Pisoxylon roosevelti is very similar structurally to the new species described in the present work, $T$. basirufum sp. nov. Many of the characters shared between $P$. roosevelti and T. basirufum sp. nov. are common to several Trypoxylon s. str., like the dilated lamellar margin on the metapleura. This is one of the diagnostic characteristics of the fabricator group in Trypoxylon s. str. In this group there are also species that have a compact abdomen combined with the absence of a propodeal lateral carina, for example, T. pachygaster Richards, 1934. Also, in our phylogenetic study of Trypoxylon sensu lato (Muniz and Melo, unpubl. data), we have found out that DNAsequence data from $T$. basirufum sp. nov. group it with other species of Trypoxylon s. str. and not with Pisoxylon amenkei as expected on morphological ground. Based on this, we propose transferring $P$. roosevelti to Trypoxylon s. str., keeping only P. amenkei and P. xanthosoma in the genus Pisoxylon.

Based on the above propositions, we reformulate the diagnosis of Pisoxylon to the following characters: inner eye orbits deeply notched; antennal sockets not contiguous with frontoclypeal suture; supraclypeal area shorter than wide; mandibles simple, having neither ventral incision (or tooth), nor inner tooth; male F6-F8 with tyloids; occipital carina incomplete and connected to the hypostomal carina in males and females; metapleura dorsally without dilated protrusion; propodeum moderately elongate-oval, without specific preapical structures; dorsal field of propodeum not clearly outlined, with medial groove; lateral carinae of propodeum absent; female hind coxa with minute subapical tubercle ventrally; hind wing with single basal hook and 2 groups of 5(6) + 3 hamuli, separated from each other by a distance about twice the length of the proximal group of hamuli; intercalary hooks absent; metasoma sessile, relatively short, with non-elongate segment I. This reformulated diagnosis is based also on the undescribed male of Pisoxylon amenkei, obtained from trap nests in Paraná, Brazil (Muniz \& Melo, unpubl. data).

\section{Trypoxylon basirufum sp. nov. (Figs. 1C, D, 2C, D, 3C, D)}

Diagnosis: Trypoxylon basirufum sp. nov. resembles T. roosevelti in the laminar dilation of dorsal margin of metapleura; shorter and flatter medial lobe of clypeus with short rectangular apical protrusion; longer supraclypeal area; entire medial carina on lower part of frons; less flattened head; entirely black mesothorax and propodeum, and relatively small size. Trypoxylon basirufum sp. nov. differs from $T$. roosevelti in being slightly more robust and in having a larger body size; the apical flagellomere of the male antenna is longer than the summed length of three preceding flagellomeres $(\mathrm{F} 11>\mathrm{F} 10+\mathrm{F} 9+\mathrm{F} 8)$; males without spine in the propleura; apical third of clypeus pale yellow; hind leg with uniform bright reddish brown; first tergum entirely bright reddish brown; pubescence mostly brassy, with some areas containing brown setae; dorsal field of propodeum not outlined, its sculpture resembling that in $P$. roosevelti but striation coarser. 
Description: Female holotype: Body length, $7.9 \mathrm{~mm}$. Head rounded in frontal view (Fig. 3C). Median clypeal lobe (Fig. 3C) flat, almost straight along lower margin, with wide and short apical protrusion. Supraclypeal area longer than its maximum basal width; raised suprantennal field of lower part of frons roof-shaped, with an-

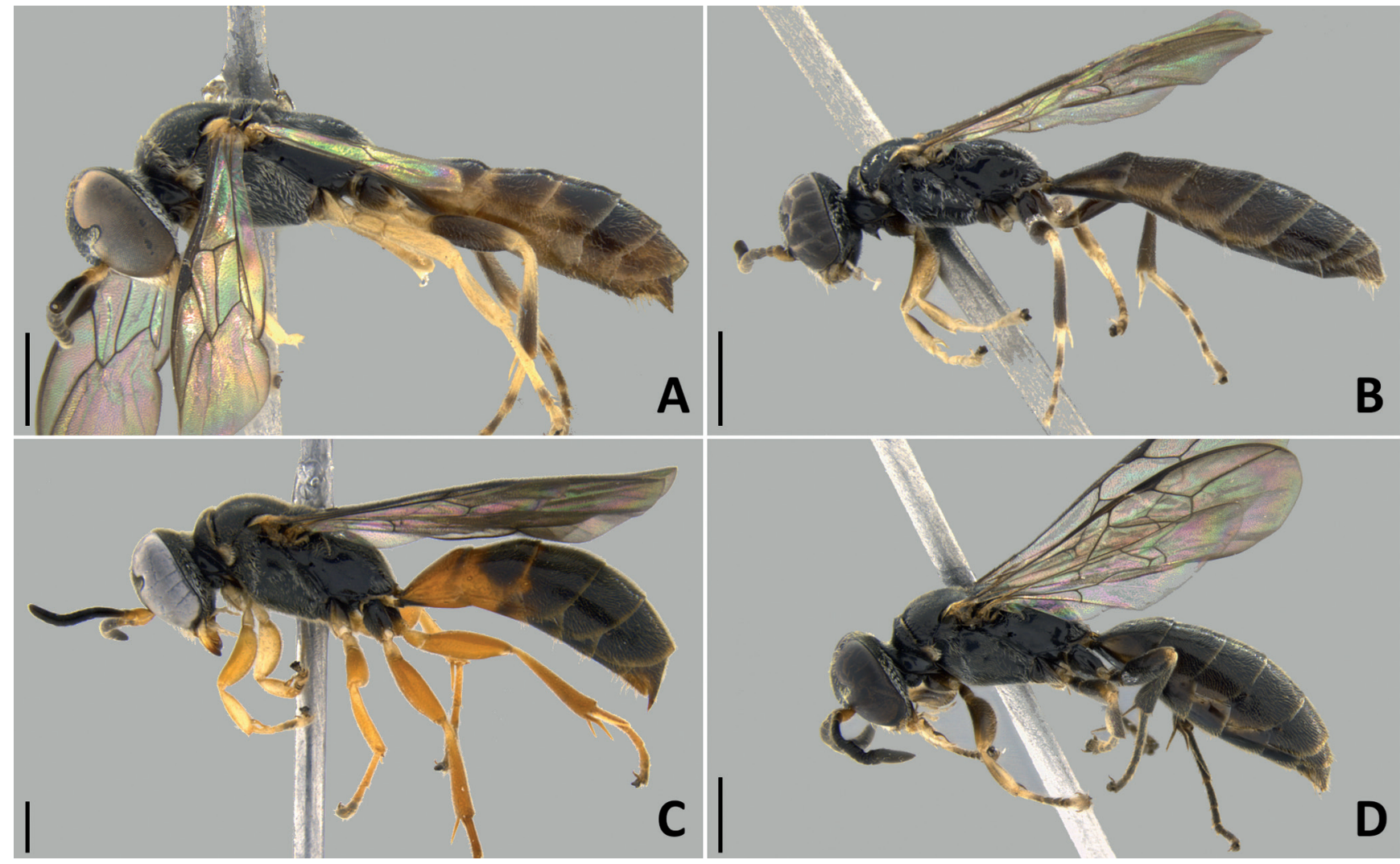

Figure 1. Habitus, lateral view. (A) Trypoxylon roosevelti (Antropov, 1998), female from Manaus, Amazonas, Brazil. (B) Trypoxylon roosevelti, male from Rio Branco, Acre, Brazil. (C) Trypoxylon basirufum sp. nov., female holotype. (D) Trypoxylon basirufum sp. nov., male paratype from Antonina, Paraná, Brazil. Scale = $1 \mathrm{~mm}$.
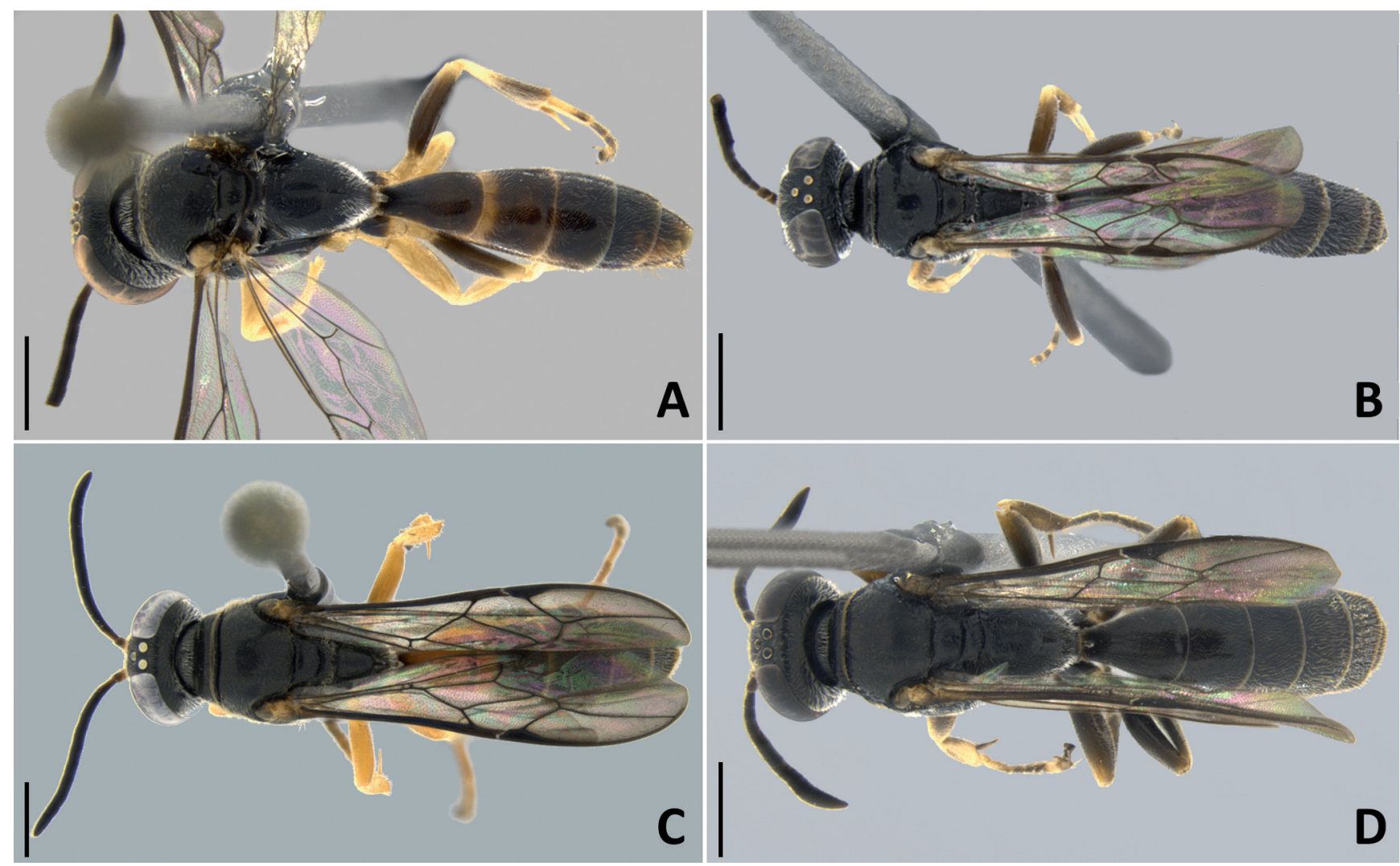

Figure 2. Habitus, dorsal view. (A) Trypoxylon roosevelti (Antropov, 1998), female from Manaus, Amazonas, Brazil. (B) Trypoxylon roosevelti, male from Rio Branco, Acre, Brazil. (C) Trypoxylon basirufum sp. nov., female holotype. (D) Trypoxylon basirufum sp. nov., male paratype from Antonina, Paraná, Brazil. Scale = $1 \mathrm{~mm}$. 
terior obtuse transverse carina connected to borders of antennal pits; medial carina on this field entire, strongly shining posteriorly, protruding as far as one-third of the distance between its apex and medial ocellus. Frons moderately (mainly in the middle) convex, with hardly visible medial groove. Pronotal ridge short, flattened medially, convex laterally, and broadly-limbate posteriorly. Mesonotum with short admedial lines anteriorly and without noticeable traces of notauli. Mesoscutellum slightly convex; metanotum clearly convex; mesopleura moderately convex; metapleura flat, with hyaline laminar dilation dorsally. Fore coxae convex anteriorly. Hind wings bearing single basal hook and 2 groups of $5+3$ hamuli each, separated by an interval twice the length of the proximal group of hamuli. Dorsal field of propodeum not outlined and slightly depressed medially, with medial groove dilated posteriorly; posterior part of propodeum with deep medial groove, except for apical portion. Tergum VI conical, with smoothed medial crest at apex.

Integument mostly smooth, microsculpture poorly developed, being distinct only on head. Frons shagreened, dull, with sparse shallow punctures (placed apart by approximately 2 puncture diameters). Pronotum with fine transverse microstriae, shiny; mesonotum with hardly visible microstriae, shiny; mesoscutellum with microstriae and sparse shallow piligerous punctures (placed apart by more than 3 puncture diameters), shiny; metanotum with fine transverse striae and punctures at hair bases, somewhat dull; metasomal terga and sterna mostly shiny, with piligerous micropunctures; tergum VI with longitudinal microstriae.

Pubescence of body sparse, yellowish with golden reflections, not concealing integument, except on clypeus and part of frons with silver reflections. Setae erect on frons and apex of propodeum, semi-decumbent on gena, pronotum, mesoscutum, mesoscutellum, metanotum, and basilateral surfaces of propodeum, and decumbent on mesopleura and metasomal segments I-V; segment VI with long sparse setae.

Integument mostly black. Lower half of clypeus (above apical rim) and base of mandibles pale yellow; apical rim of clypeus reddish yellow. Scape, pedicel ventrally, postero-ventral part of mesopleura (anteriorly to mid coxae), fore coxa, fore trochanter, fore femur, entire fore tibia, fore basitarsus varying from pale to reddish yellow; first flagellomere, tegula, apical parts of mid and hind coxae, ventral part of mid and hind trochanters, mid and hind femora, entire hind tibiae, entire hind tarsomeres, most of metasomal segment I, anterior onethird of tergum II and anterior half of sternum II bright
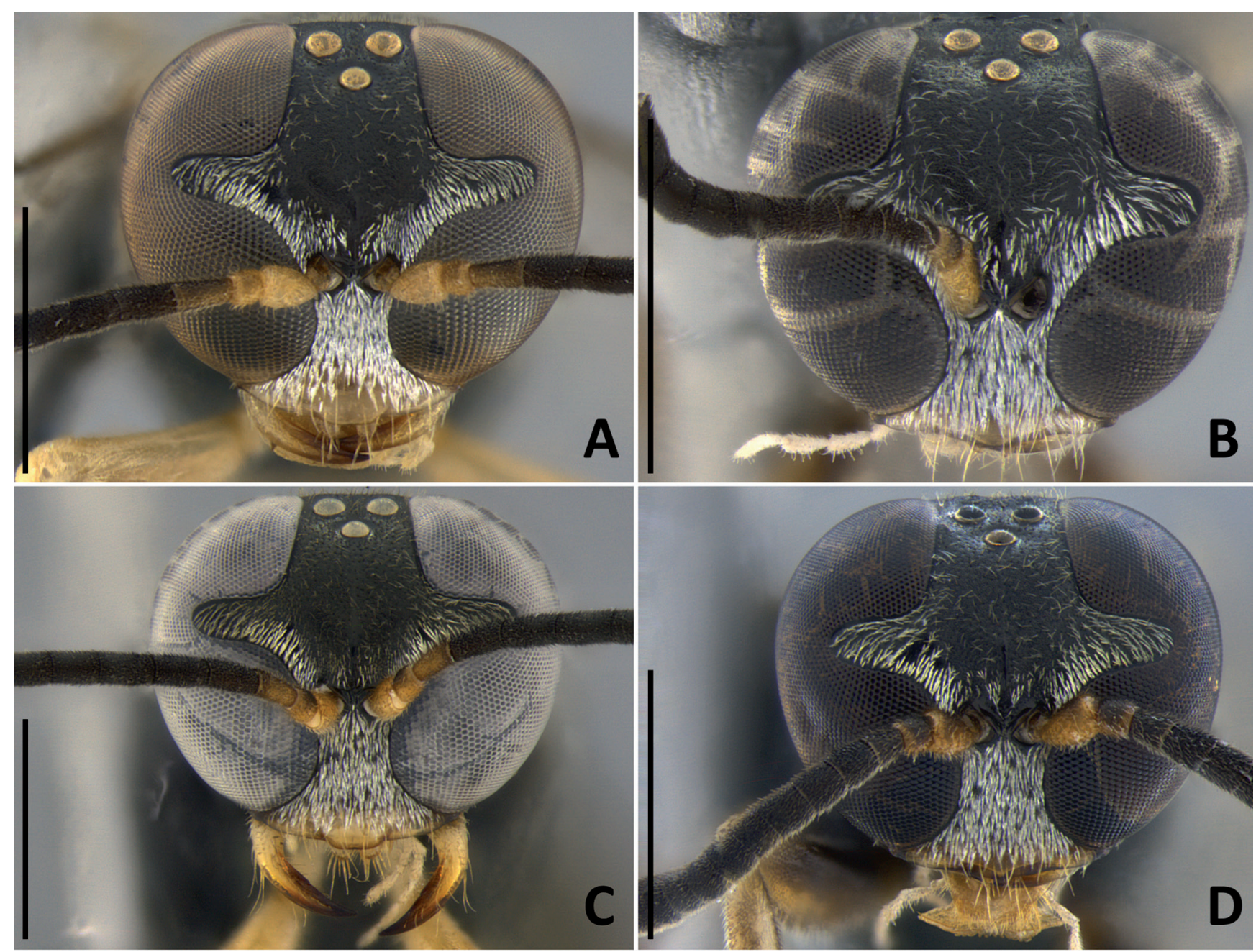

Figure 3. Head, frontal view. (A) Trypoxylon roosevelti (Antropov, 1998), female from Manaus, Amazonas, Brazil. (B) Trypoxylon roosevelti, male from Rio Branco, Acre, Brazil. (C) Trypoxylon basirufum sp. nov., female holotype. (D) Trypoxylon basirufum sp. nov., male paratype from Antonina, Paraná, Brazil. Scale = $1 \mathrm{~mm}$. 
reddish brown; basal parts of mid and hind coxae, ventral spots on sternum I, posterior portion of tergum II, sterna III-V and terga III-VI dark-brown; sternum VI mostly dark reddish brown.

Male: Body length, $7.7 \mathrm{~mm}$. Head rounded in frontal view (Fig. 3D). Median clypeal lobe (Fig. 3D) flat, almost straight along lower margin, with narrow and subtle apical semicircular protrusion. Supraclypeal area longer than its maximum basal width; raised suprantennal field of lower part of frons roof-shaped, with anterior obtuse transverse carina connected to borders of antennal pits; medial carina on this field entire, strongly shining posteriorly, protruding as far as one-third of the distance between its apex and medial ocellus. Frons moderately (mainly in the middle) convex, with hardly visible medial groove. Transverse carina of propleura not forming a large spine in the medial region. Pronotal ridge short, flattened medially, convex laterally, and broadly-limbate posteriorly. Mesonotum with short admedial lines anteriorly and without noticeable traces of notauli. Mesoscutellum slightly convex; metanotum clearly convex; mesopleura moderately convex; metapleura flat, with hyaline laminar dilation dorsally. Fore coxae convex anteriorly. Hind wings bearing single basal hook and 2 groups of 5 or $4+3$ hamuli each, separated by an interval twice the length of the proximal group of hamuli. Dorsal field of propodeum not outlined and slightly depressed medially, with medial groove dilated posteriorly; posterior part of propodeum with deep medial groove, except for apical portion. Tergum VII conical, without smoothed medial crest at apex.

Integument mostly smooth, microsculpture poorly developed, being distinct only on head. Frons shagreened, dull, with sparse shallow punctures (placed apart by approximately 2 puncture diameters). Pronotum with fine transverse microstriae, shiny; mesonotum with hardly visible microstriae, shiny; mesoscutellum with microstriae and sparse shallow piligerous punctures (placed apart by more than 3 puncture diameters), shiny; metanotum with fine transverse striae and punctures at hair bases, somewhat dull; metapleura and anterior half of lateral part of propodeum shiny, without punctures; metasomal terga and sterna mostly shiny, with piligerous micropunctures; tergum VII with longitudinal microstriae.

Pubescence of body sparse, yellowish with golden reflections, not concealing integument, except on clypeus and part of frons with silver reflections. Setae erect on frons and apex of propodeum, semi-decumbent on gena, pronotum, mesoscutum, mesoscutellum, metanotum, and basilateral surfaces of propodeum, and decumbent on mesopleura and metasomal segments I-Vl; segment VII ventrally with long sparse setae.

Integument mostly black. Lower third of clypeus (above apical rim) and base of mandibles pale yellow; apical rim of clypeus reddish yellow. Scape ventrally, pedicel ventrally, tegula, postero-ventral part of mesopleura (anteriorly to mid coxae), part of fore tibia, base of fore basitarsus varying from pale to reddish yellow; flag- ellomeres, coxae, trochanters, mid and hind femora, entire mid and hind tibiae, entire mid and hind tarsomeres, and metasomal segments dark brown.

Type material: Holotype: $q$ (DZUP): BRAZIL: 'Brasil, PR, Antonina, \R N Guaricica, 115 m, \ 16-20.

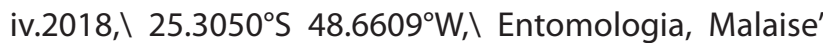
'HOLOTYPE\ Trypoxylon basirufum\ Muniz \& Melo, 2020'. Paratypes (13\%, 30'): BRAZIL: Paraná: 'Brasil, Paraná, Antonina, \RNRC, -25.2836, -48.6646, \03.I.2017, C.Costa, ninho-armadilha: C21' (69, DZUP); 'Brasil, Paraná, Antonina, $\backslash$ RNRC, -25.2836, -48.6646,\03.I.2017, C.Costa, ninho-armadilha: C22' (5ㅇ, DZUP); 'Brasil, PR, Antonina $\backslash$ Res. Rio Cachoeira $\backslash 25.315^{\circ} \mathrm{S} 48.696^{\circ} \mathrm{W} \backslash 50 \mathrm{~m}$, 23-27.i.2017 Entomologia UFPR' 'Armadilha\malaise' (10", DZUP); 'Brasil, Paraná, Antonina\ RN Guaricica,

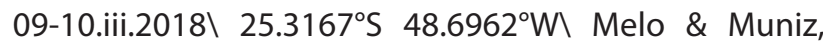
Malaise' (10', DZUP). São Paulo: 'Brasil, SP, Cananéia, Ilha do Cardoso, $\backslash 25.0861^{\circ} \mathrm{S} 47.9633^{\circ} \mathrm{W} \backslash \backslash 24 . x i .2015$, P.S. Vilhena, trap-nest "T.784"' 'GARÓFALO \Coleção do Prof. Dr. C.A. Garófalo\ USP Ribeirão Preto' (2\%, 10“, RPSP).

\section{Distribution records: BRAZIL: Paraná: Antonina; São Paulo: Cananéia.}

Etymology: The species is named in reference to the reddish color of the basal metasomal segments in the female, from the Latin basis, base, foundation and rufus, red, reddish.

\section{Trypoxylon roosevelti (Antropov, 1998) comb. nov.} (Figs. 1A, B, 2A, B, 3A, B, 4A-D)

Pisoxylon roosevelti Antropov, 1998: 907. Holotype female, Bolivia: Santa Cruz, Río Mamore, 2 km north of mouth of Río Chapare (AMNH, examined through photographs).

Diagnosis: Trypoxylon roosevelti differs from T. basirufum sp. nov. in being more slender and slightly smaller; the apical flagellomere of the male antenna is shorter than the summed length of three preceding flagellomeres $(\mathrm{F} 11>\mathrm{F} 10+\mathrm{F} 9+\mathrm{F} 8)$; males with transverse carina of propleura forming a large spine in the medial region; apical half of clypeus pale yellow (except on the male); hind leg with the areas near articulations pale yellow (apex of coxa, entire trochanter, apex of femur, base of tibiae and base of first tarsomere); first tergum mostly dark brown; pubescence with silver reflections.

Description: Male (previously undescribed). Body length, $7.5 \mathrm{~mm}$. Head rounded in frontal view (Fig. 3B). Median clypeal lobe (Fig. 3B) flat, almost straight along lower margin, with narrow and short apical semicircular protrusion. Supraclypeal area longer than its maximum basal width; raised suprantennal field of lower part of frons roof-shaped, with anterior obtuse transverse carina connected to borders of antennal pits; medial carina on this field entire, strongly shining posteriorly, protruding 

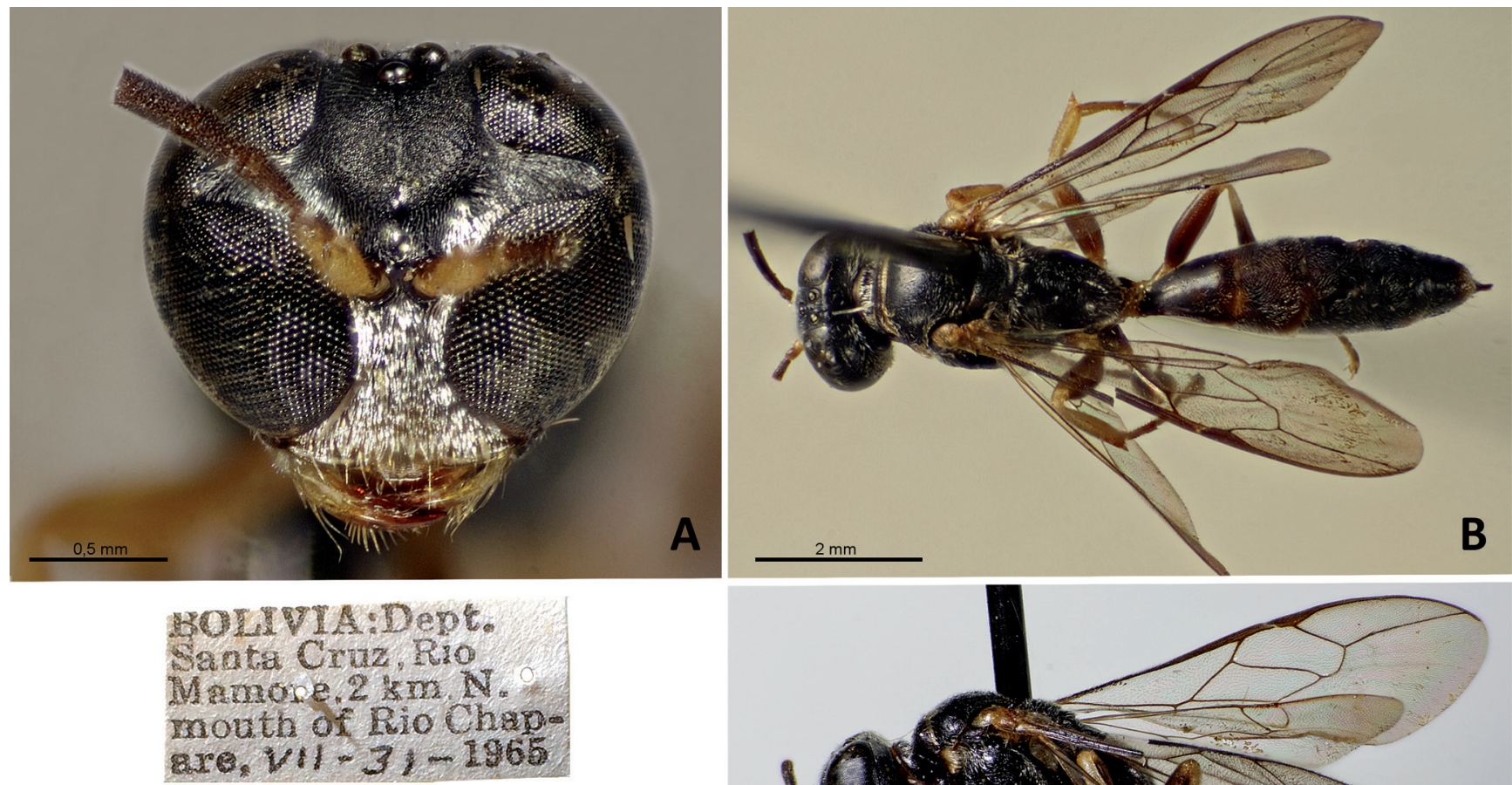

J.K. Bouseman Callector
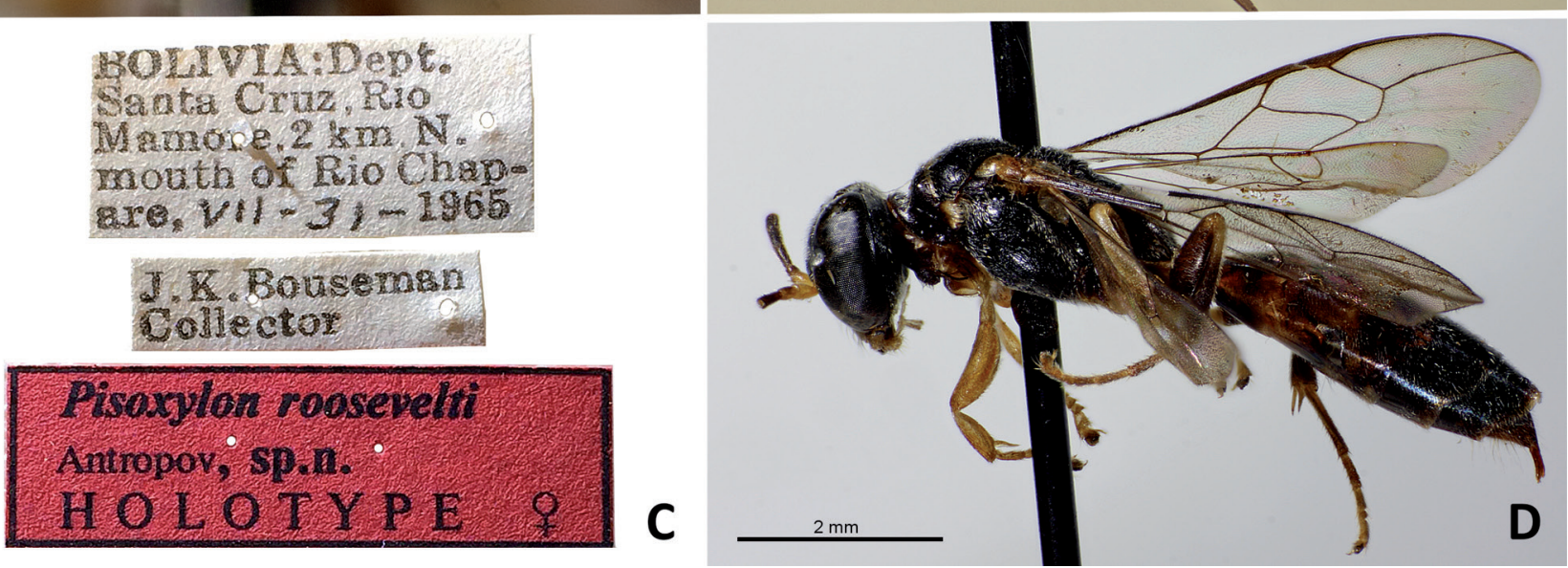

Figure 4. Holotype female of Pisoxylon roosevelti Antropov, 1998. (A) Head, frontal view. (B) Habitus, dorsal view. (C) Specimen labels. (D) Habitus, lateral view.

as far as one-third of the distance between its apex and medial ocellus. Frons moderately (mainly in the middle) convex, with hardly visible medial groove. Transverse carina of propleura forming a large spine in the medial region. Pronotal ridge short, flattened medially, convex laterally, and broadly-limbate posteriorly. Mesonotum with short admedial lines anteriorly and without noticeable traces of notauli. Mesoscutellum slightly convex; metanotum clearly convex; mesopleura moderately convex; metapleura flat, with hyaline laminar dilation dorsally. Fore coxae convex anteriorly. Hind wings bearing single basal hook and 2 groups of $4+3$ hamuli each, separated by an interval twice the length of the proximal group of hamuli. Dorsal field of propodeum not outlined and slightly depressed medially, with medial groove dilated posteriorly; posterior part of propodeum with deep medial groove, except for apical portion. Tergum VII with truncated apex, without smoothed medial crest at apex.

Integument mostly smooth, microsculpture poorly developed, being distinct only on head. Frons shagreened, dull, with sparse shallow punctures (placed apart by approximately 2 puncture diameters). Pronotum with fine transverse microstriae, shiny; mesonotum with hardly visible microstriae, shiny; mesoscutellum with microstriae and sparse shallow piligerous punctures (placed apart by more than 3 puncture diameters), shiny; metanotum with fine transverse striae and punctures at hair bases, somewhat dull; metapleura and anterior half of lateral part of propodeum shiny, without punctures; metasomal terga and sterna mostly shiny, with piligerous micropunctures; tergum VII with longitudinal microstriae.

Pubescence of body sparse, with silver reflections, not concealing integument. Setae erect on frons and apex of propodeum, semi-decumbent on gena, pronotum, mesoscutum, mesoscutellum, metanotum, and basilateral surfaces of propodeum, and decumbent on mesopleura and metasomal segments I-VI; segment VII ventrally with long sparse setae.

Integument mostly black. Lower third of clypeus (above apical rim) and base of mandibles pale yellow; apical rim of clypeus reddish yellow. Maxillary palp, labial palp, scape ventrally, pedicel ventrally, tegula, postero-ventral part of mesopleura (anteriorly to mid coxae), apex of fore coxa, fore trochanter ventrally, fore femur ventrally, fore tibia ventrally, entire fore basitarsus, basal parts of mid and hind tibiae, basal parts of mid and hind basitarsus and tarsus varying from whitish to pale yellow; propleura, fore, mid and hind coxa, mid and hind trochanters, mid and hind femora, most of the hind tibiae, basal parts of hind basitarsus, and all metasomal segments dark-brown.

Remarks: Antropov (1998) proposed this species based on a single female from Santa Cruz, in Bolivia. Here we record it for the first time in Brazil, with additional speci- 
mens from central and western Amazon basin. The previously undescribed male resembles the male of T. basirufum sp. nov. in general appearance, differing primarily in body size and details of color and shape (see Diagnosis and Description above).

Distribution records: BOLIVIA: Santa Cruz: Río Mamore $2 \mathrm{~km}$ north of mouth Río Chapare; BRASIL: Acre: Rio Branco; Amazonas: Manaus; Rondônia: Vilhena.

Type material: Holotype female, with the labels'BOLIVIA: Dept.I Santa Cruz. Riol Mamore, $2 \mathrm{~km} \mathrm{N.I} \mathrm{mouth} \mathrm{of}$ Rio Chap-\ are, VII-31-1965' 'J.K.Bouseman\Collector' 'Pisoxylon roosevelti Antropov, sp. n.I HOLOTYPE ${ }^{\prime}$ '. Missing F3-F10 in the left antenna and F4-F10 in the right antenna.

Additional examined material: BRAZIL: Acre: 'Brasil, Acre, Rio Branco,\ Parque Zoobotânico,\ 09²15'S, 6700'W, 07-23.vii\ 1998, Elder F. Morato, \Armadilha Malaise' (19, DZUP); 'Brasil, Acre, Rio Branco, \ Parque Zoobotânico, $\quad 09^{\circ} 15^{\prime} \mathrm{S}, \quad 67^{\circ} 00^{\prime} \mathrm{W}$, 02-09.ix.l 1998, Silva, Selhorst \&\ Reis, Armadilha Malaise' (10", DZUP); Amazonas: 'Brasil, Amazonas, \Manaus, Res. Ducke, $\backslash$ 0256'S, 5958'W \ 29.vii. 1999, G.Melo, \ coletando barro' (29, DZUP); Rondônia: 'Vilhena, RO \27/12/1986\ C.Elias, leg.\POLONOROESTE' (19, DZUP).

\section{ACKNOWLEDGMENTS}

We thank the staff of the depository institutions for providing material and information on type material under their care. We also thank André Martins, Brunno Rosa and Ana Vasconcelos for taking pictures of the type specimens, and Michael Ohl and one anonymous reviewer for providing helpful remarks on the manuscript. Maria Luisa Buschini, Rodrigo Gonçalves, Camila Costa, Carlos Alberto Garófalo and Patrícia Vilhena are thanked for making available specimens obtained in their trap-nesting studies. The work was supported by CAPES (Ph.D. scholarship to DBM) and CNPq (grant 309641/2016-0 to GARM).

\section{AUTHORS' CONTRIBUTIONS}

D.B.M.: Prepared the specimens for taxonomy; identified, described the species and revised the literature; took the photographs and prepared the figures; prepared the manuscript and review; ensured standardization and following of journal norms. G.A.R.M.: Supervision, assisted in writing manuscript and review. All authors approved the final manuscript.

\section{REFERENCES}

Amarante, S.T.P. 1995. Trypoxylon (Trypoxylon) mojuba, sp. n., an unusual Trypoxylini from South America (Hymenoptera, Sphecidae). Revista Brasileira de Entomologia, 39(1): 157-160.

Amarante, S.T.P. 2002. A synonymic catalog of the neotropical Crabronidae and Sphecidae (Hymenoptera: Apoidea). Arquivos de Zoologia, 34: 1-139.

Amarante, S.T.P. 2005. Addendum and corrections to a synonymic catalog of Neotropical Crabronidae and Sphecidae. Papéis Avulsos de Zoologia, 45: 1-18.

Antropov, A.V. 1998. Digger Wasps of the Genus Pisoxylon (Hymenoptera, Sphecidae, Trypoxylini). Entomological Review, 78(6): 761-767. Translated from Zoologicheskii Zhurnal, 77(8).

Bohart, R.M. \& Menke, A.S. 1976. Sphecid wasps of the world. A generic revision. Berkeley, University of California Press. 695p.

Menke, A.S. 1968. New genera and species of wasps of the tribe Trypoxylini from the Neotropical Region. Los Angeles County Museum Contributions in Science, 135: 1-9.

Morato, E.F. \& Campos, L.A. de 0. 1994. Aspectos da biologia de Pisoxylon xanthosoma Menke, 1968 na Amazônia Central (Hymenoptera, Sphecidae, Larrinae, Trypoxylini). Revista Brasileira de Entomologia, 38(3/4): 585-594.

Pulawski, W.J. 2020. Catalog of Sphecidae sensu lato (= Apoidea excluding Apidae). Available: https://www.calacademy.org/scientists/projects/ catalog-of-sphecidae. Access: 10/08/2020.

Richards, 0.W. 1934. The American species of the genus Trypoxylon (Hymenopt., Sphecoidea). Transactions of the Royal Entomological Society of London, 82: 173-362. 